\title{
PENGARUH PENAMBAHAN COD LIVER OIL PADA PAKAN KOMERSIAL TERHADAP KANDUNGAN OMEGA-3 (EPA DAN DHA) DI DAGING UDANG GALAH (Macrobrachium rosenbergii)
}

\section{Effect of Cod Liver Oil Addition to Feed the Commercial Content of Omega-3 (EPA and DHA) in Galah Shrimp Meat (Macrobrachium rosenbergii)}

\author{
Ellavida Anindya ${ }^{1 *}$, Agustono,Ir.,M.Kes ${ }^{2}$ dan Boedi Setya Rahardja,Ir.,M.P ${ }^{2}$ \\ ${ }^{1}$ Program Studi Budidaya Perairan, Fakultas Perikanan dan Kelautan, Universitas Airlangga, Surabaya \\ ${ }^{2}$ Departemen Manajemen Kesehatan Ikan dan Budidaya Perairan, Fakultas Perikanan dan Kelautan, Universitas \\ Airlangga, Surabaya \\ *ellavida37@gmail.com
}

\begin{abstract}
Abstrak
Udang galah (Macrobrachium rosenbergii) merupakan salah satu komoditas perikanan yang mempunyai nilai perdagangan ekonomi yang memiliki prospek. Permintaan pasar dalam negeri dan luar negeri terhadap udang galah cukup tinggi menjadikan Indonesia sebagai pengirim udang galah di dunia. Asam lemak omega-3 merupakan asam lemak karboksilat yang posisi ikatan rangkap pertamanya terletak pada atom karbon nomor tiga dari ujung gugus metilnya. Omega-3 asam lemak tak jenuh yang sangat penting untuk kesehatan udang galah. Derivat asam lemak omega-3 salah satunya eicosapentaenoic acid (EPA) dan Decosaheksaenoic acid (DHA) termasuk dalam asam lemak esensial. Sumber asupan asam lemak omega-3 dapat dihasilkan salah satunya dengan penambahan minyak hati ikan kod. Penelitian ini bertujuan untuk mengetahui pengaruh penambahan Cod Liver Oil pada pakan komersial terhadap kandungan eicosapentaenoic acid (EPA) dan Dekosaheksaenoic acid (DHA) pada daging udang galah (Macrobrachium rosenbergii ). Metode penelitian ini menggunakan rancangan Acak Lengkap (RAL) dan perlakuan yang dilakukan dalam penelitian ini menggunakan perbedaan dosis cod liver oil (CLO) yang berbeda yaitu P0 sebagai kontrol dengan dosis CLO 0\%,P1 dosis CLO 3\%,P2 dosis CLO 6\%, P3 dosis CLO 9\%, dan P4 dosis CLO 12\%. Setiap perlakuan dilakukan ulangan 4 kali. Hasil penelitian ini menggunakan cod liver oil terhadap kandungan DHA tidak berbeda nyata $(\mathrm{P}>0,05)$. Sedangkan untuk kandungan EPA berbeda nyata $(\mathrm{P}<0,05)$. Untuk dosis tertinggi pada kandungan EPA pada perlakuan P4 dengan dosis cod liver oil 12\% dan DHA didapatkan hasil tertinggi pada perlakuan P2 dosis cod liver oil 6\%.
\end{abstract}

Kata Kunci: Cod Liver Oil, Udang Galah (Macrobrachium rosenbergii), Omega-3, EPA, DHA

\begin{abstract}
Prawns (Macrobrachium rosenbergii) is the one commodity that has a value of trade economic prospects. Market demand domestically and abroad against prawns high enough to make Indonesia as the sender Galah shrimp in the world. Omega-3 is a fatty acid carboxylic first double bond position is located at the number three carbon atoms from the end of the group metilnya. Omega-3 polyunsaturated fatty acids which are essential to the health of prawns. Derivatives of omega-3 one eicosapentaenoic acid (EPA) and Dekosaheksaenoic acid (DHA) are included in the essential fatty acids. Sources intake of omega-3 fatty acids can be produced either by addition of cod liver oil. This study aimed to determine the effect of Cod Liver Oil in commercial feed on the content of eicosapentaenoic acid (EPA) and Dekosaheksaenoic acid (DHA) on meat prawns (Macrobrachium rosenbergii). This research method uses design of completely randomized (CRD) and the treatment is performed in this study using the difference doses of cod liver oil (CLO) that is different is to use P0 as a control with a dose of CLO 0\%, P1 dose of CLO 3\%, P2 dose of CLO 6\%, P3 dose of CLO 9\%, P4 dose of CLO 12\%. Then do repeat 4 times. The results of this study using the cod liver oil DHA content was not significantly different $(\mathrm{P}>0.05)$. While the EPA content was significantly different $(\mathrm{P}<0.05)$. For the highest dose in the EPA content in P4 treatment with a dose of cod liver oil 12\% and DHA obtained the highest results at treatment doses of cod liver oil P2 6\%.
\end{abstract}

Keywords: Cod Liver Oil, Prawns (Macrobrachium rosenbergii), Omega-3, EPA, DHA 


\section{PENDAHULUAN}

Udang galah (Macrobrachium rosenbergii) merupakan salah satu komoditas perikanan yang mempunyai nilai perdagangan ekonomi yang memiliki prospek. Permintaan pasar dalam negeri dan pasar luar negeri terhadap udang galah cukup tinggi menjadikan Indonesia sebagai pengirim udang galah di dunia. (Pusat Penyuluhan dan Perikanan, 2011).

Permintaan udang sangat besar baik pasar lokal maupun internasional, karena komoditas tersebut memiliki keunggulan nilai gizi yang sangat tinggi serta memiliki nilai ekonomis yang cukup tinggi pula sehingga menyebabkan budidaya udang semakin pesat (Yustianti, 2013). Kebutuhan masyarakat dunia terhadap protein hewani terus meningkat seiring dengan peningkatan populasi penduduk dunia. Oleh karena itu sektor budidaya udang diharapkan dapat menjadi solusi dalam pemenuhan kon-sumsi kebutuhan gizi di dunia. Salah-satu faktor yang berperan penting menentukan keberhasilan budidaya yaitu pakan. (Yustianti, 2013).

Menurut Chedoloh et al. (2011), udang galah mengandung omega-3 pada daging sebanyak 24,7mg/100gram. Udang memiliki kemampuan yang terbatas dalam elongasi dan desaturasi linolenat untuk mengubah EPA dan DHA. EPA dan DHA termasuk kedalam asam lemak tak jenuh (Poly Unsaturated Fatty Acid/PUFA) adalah asam lemak yang mengandung dua atau lebih ikatan rangkap (Ayu, 2008).

Asam lemak linolenat atau omega3 ini mempunyai manfaat untuk udang yaitu untuk ketahanan tubuh udang, mempercepat pertumbuhan dan metabolisme udang galah, menurunkan Low Density Lipoprotein (LDL) dan menaikkan High Density Lipoprotein (HDL). Pada manusia asam lemak omega-3 berperan sebagai pencegahan penyakit jantung koroner, menurunkan kolestrol Low Density Lipoprotein (LDL) dan menaikkan High Density Lipoprotein (HDL), juga untuk meningkatkan kecerdasan otak dan untuk kesehatan retina mata (Ayu, 2008).
Menurut (Halver, 1989) untuk mencukupi kebutuhan omega-3 diperlukan suplai omega-3 dari pakan yang dikonsumsi udang tersebut.

Salah satu upaya yang harus dilakukan untuk menambah kadar omega-3 pada daging udang galah dengan penambahan Cod liver oil pada pakan komersial. Cod liver oil banyak mengandung omega3 (EPA dan DHA). Oleh karena itu dilakukan penelitian mengenai pengaruh penambahan Cod liver oil pada pakan komersial terhadap kandungan omega-3 (EPA dan DHA) di daging udang galah sehingga baik untuk dikonsumsi masyarakat.

\section{METODOLOGI \\ Waktu dan Tempat}

Penelitian ini dilaksanakan di Laboratorium Perikanan dan Kelautan Universitas Airlangga Surabaya pada bulan Mei sampai dengan bulan Juni 2016. Analisis bahan baku pakan komersial dan analisis kandungan asam lemak yaitu omega-3 (EPA dan DHA) dan Analisis kandungan cod liver oil di daging udang galah dilakukan di Laboratorium Farmasi Universitas Airlangga Surabaya.

\section{Materi Penelitian}

Peralatan Penelitian

Alat-alat yang digunakan dalam penelitian ini adalah 20 buah akuarium ukuran 40x20x25 $\mathrm{cm}^{3}$, aerator, selang aerasi dan batu aerasi, selang sipon, bak plastik besar, timbangan digital, gelas ukur, $\mathrm{pH}$ pen, termometer, DO meter, amonia test kit dan refraktometer.

\section{Bahan Penelitian}

Bahan yang digunakan dalam penelitian ini adalah udang galah dengan berat rata-rata \pm 10 gram/ekor sebanyak 140 ekor (Yola, 2015). Udang galah didapatkan dari Unit Pengelola Perikanan Budidaya (UPPB) Prigi, Trenggalek, Jawa Timur. Jumlah daging yang dibutuhkan untuk pengujian di Unit Laboratorium Penelitian Farmasi Unair sebanyak 10 
gram. Media pemeliharaan dalam penelitian ini adalah akuarium dengan diisi air tawar. Pengisian air tawar sebanyak 15 liter pada setiap akuarium.

\section{Metode Penelitian}

Metode yang digunakan dalam penelitian ini adalah metode eksperimental untuk mengetahui pengaruh penambahan Cod Liver Oil (CLO) terhadap kandungan omega-3 (EPA dan DHA) pada daging udang galah. Rancangan penelitian ini menggunakan Rancangan Acak Lengkap (RAL) dengan satu sumber keragaman yaitu Cod Liver Oil (CLO).

\section{Prosedur Kerja \\ Persiapan Alat dan Bahan}

Persiapan yang dilakukan adalah membersihkan dengan cara dicuci sampai bersih menggunakan sabun dan klorin sebelum akuarium digunakan. Akuarium yang telah dibersihkan menggunakan klorin kemudian dibilas dengan air bersih dan dikeringkan. Tujuannya untuk menghilangkan kotoran dan bibit-bibit penyakit sehingga ketika pemeliharaan udang galah dapat tumbuh dengan baik dan sehat terhindar dari bibit penyakit.

Apabila akuarium telah dalam kondisi bersih dan kering dilakukan pengisian air tawar sebanyak 15 liter pada setiap akuarium. Setelah dilakukan pengisian air pada akuarium maka diberikan aerasi selama 24 jam untuk meningkatkan oksigen terlarut dan menghilangkan bahan kimia yang ada dalam akuarium tersebut. Sebelum dilakukan perlakuan, udang galah diaklimatisasi dahulu selama tiga hari agar udang galah dapat menyesuaikan diri dengan lingkungan perairan yang baru. Kemudian udang galah dipuasakan selama satu hari untuk menghilangkan pengaruh pakan sebelumnya. Banyaknya udang galah yang dipelihara pada setiap akuarium sebanyak 7 ekor menurut Fatagar (2014). Pakan yang diberikan untuk udang galah berupa pakan komersial merk Feng Li yang ditambahkan cod liver oil merk Baby”s DHA dan tepung tapioka sebagai perekat. Semua bahan-bahan penyusun pakan disiapkan dan ditimbang sesuai dosis yang ditentukan. Pakan komersial digiling terlebih dahulu agar menjadi bentuk tepung kemudian ditambahkan cod liver oil serta dicampurkan dengan tepung tapioka yang dilarutkan air hangat. Bahanbahan tersebut diaduk hingga adonan menjadi tercampur. Bahan-bahan yang telah tercampur dicetak kembali menjadi bentuk pelet. Pakan dioven dengan suhu $50^{\circ} \mathrm{C}$ selama 24 jam. Tujuan pengovenan yaitu untuk mengurangi kadar air serta menambah daya simpan pakan. Pakan yang sudah jadi dianalisa proksimat untuk mengetahui kandungan nutrisi pakan.

\section{Prosedur Uji}

Prosedur uji ada 2 tahap yaitu tahap pertama daging udang galah yang dalam keadaan beku disiram menggunakan air bersih kemudian ditiriskan, daging udang ditimbang sebanyak 5 gram kemudian dicingcang hingga halus. Langkah selanjutnya daging udang dimasukkan ke dalam tabung ditambahkan Na sulfat sebanyak 1 gram tujuannya pada saat ditam-bahkan hexan tidak terjadi emulsi lalu ditambahkan heksan sebanyak 10-15 ml kemudian divortex selama 3-5 menit tujuannya untuk ekstraksi minyak. Setelah itu dipindahkan minyak+hexan pada tabung lain dengan keadaan daging telah dipisah, lalu disemprotkan nitrogen sampai keadaan kering. Langkah selanjutnya ditambahkan $\mathrm{NaOH}$ sebanyak $1 \mathrm{ml}$ kemudian dipanaskan di atas water bath (penangas air) dengan suhu $90^{\circ} \mathrm{C}$ selama 5 menit ditambahkan reagen brom trifurida sebanyak $1 \mathrm{ml}$ kemudian tabung ditutup tetapi jangan sampai kering. Kemudian dipanaskan water bath dengan suhu $90^{\circ} \mathrm{C}$ selama 30 menit kemudian ditambahkan hexan sebanyak $2 \mathrm{ml}$. Kemudian tahapan kedua, bahan divortex selama 1 menit lalu diinjeksi diambil 1 mikro lalu dibaca pada alat chromatografi gas selama 20 menit. Hasil data asam lemak pada alat chronatografi gas kemudian akan keluar pada layar komputer.

Diterima/submitted:8 September 2016 Disetujui/accepted:16 Desember 2016 


\section{Analisis Data}

Analisa data penelitian diolah menggunakan analysis of varian (ANOVA) dan menggunakan metode Rancangan Acak Lengkap (RAL). Apabila didapatkan hasil adanya pengaruh yang nyata atau signifikan maka dilanjutkan dengan uji jarak berganda Duncan (Duncan mutiple range test) (Kusriningrum 2012). Data diolah menggunakan SPSS versi 16.00 .

\section{HASIL DAN PEMBAHASAN}

Hasil perhitungan kandungan Eicosapentaenoic acid (EPA) pada daging udang galah (Macrobrachium rosenbergii) setelah dilakukan pemeliharaan 30 hari dan dilakukan pengujian di Unit Layanan Pengujian (ULP) Fakultas Farmasi Universitas Airlangga didapatkan hasil kisaran EPA pada daging udang galah dengan ratarata $3,63-5,24 \%$. Data rata-rata EPA terdapat pada Tabel 1 .

Tabel 1. Rata-rata nilai Eicosapentaenoic acid (EPA) daging udang galah (Macrobrachium rosenbergii)

\begin{tabular}{cc}
\hline Perlakuan & EPA (\%) \pm SD \\
\hline P0 (Cod liver oil 0 \%) & $3,9^{\mathrm{c}} \pm 0,73$ \\
P1 (Cod liver oil 3\%) & $3,63^{\mathrm{bc}} \pm 0,43$ \\
P2 (Cod liver oil 6\%) & $4,69^{\mathrm{ab}} \pm 0,63$ \\
P3 (Cod liver oil 9\%) & $5,01^{\mathrm{ab}} \pm 0,86$ \\
P4 (Cod liver oil 12\%) & $5,24^{\mathrm{a}} \pm 0,61$ \\
\hline
\end{tabular}

Hasil perhitungan Analysis of $\mathrm{Va}$ riant (ANOVA) menunjukan adanya perbedaan nyata $(p<0,05)$. Berdasarkan hasil Uji Jarak Berganda Duncan (Duncan's Multiple Range Test) menunjukan antara perlakuan P0 dosis cod liver oil 0\% sebagai kontrol berbeda nyata dengan perlakuan P4 (12\%), P3 (9\%) dan P2 (6\%). Pada perlakuan P0 Hasil Uji Jarak Berganda Duncan (Duncan's Multiple Range Test) menunjukkan hasil tertinggi EPA terdapat pada perlakuan dosis cod liver oil P4 12\% dan dosis terendah ter- dapat pada perlakuan P1 dengan dosis cod liver oil 3\%.

Rata-rata EPA pada perlakuan P0 dengan dosis cod liver oil (0\%) menunjukkan angka 3,97\% kemudian mengalami penurunan EPA pada perlakuan P1 dengan dosis cod liver oil 3\% dengan rata-rata EPA sebesar 3,63\%. Kemudian pada perlakuan P2 dengan dosis cod liver oil 6\% mengalami peningkatan EPA 4,69\%. Perlakuan P3 dengan dosis cod liver oil 9\% mengalami peningkatan EPA 5,01\% dan perlakuan $\mathrm{P} 4$ dengan dosis cod liver oil $12 \%$ juga mengalami peningkatan kandungan EPA 5,24\%. Pada penelitian kandungan EPA dosis tertinggi terdapat pada perlakuan P4 (12\%) yaitu 5,24\% sedangkan dosis terendah terdapat pada perlakuan P1 (3\%) yaitu 3,63\%.

Sedangkan hasil perhitungan Docosahexaenoic acid (DHA) pada daging udang galah (Macrobrachium rosenbergii) didapatkan kisaran Docosahexaenoic acid (DHA) pada daging udang galah yaitu $1,51-2,22 \%$. Data rata-rata Docosahexaenoic acid (DHA) terdapat pada Tabel 2.

Tabel 2. Rata-rata nilai Docosahexaenoic acid (DHA) daging udang galah (Macrobrachium rosenbergii)

\begin{tabular}{cc}
\hline \multicolumn{1}{c}{ Perlakuan } & $\begin{array}{c}\text { DHA(\%) } \pm \\
\text { SD }\end{array}$ \\
\hline P0 (Cod liver oil 0 \%) & $1,51^{\mathrm{a}} \pm 0,80$ \\
P1 (Cod liver oil 3\%) & $1,64^{\mathrm{a}} \pm 0,64$ \\
P2 (Cod liver oil 6 \%) & $2,47^{\mathrm{a}} \pm 1,38$ \\
P3 (Cod liver oil 9\%) & $2,15^{\mathrm{a}} \pm 0,98$ \\
P4 (Cod liver oil 12\%) & $2,22^{\mathrm{a}} \pm 1,00$ \\
\hline
\end{tabular}

Hasil perhitungan Analysis of Variant (ANOVA) menunjukan hasil tidak berbeda nyata $(\mathrm{p}>0,05)$. Berdasarkan dari hasil uji jarak berganda Duncan menunjukan hasil tidak berbeda nyata antara P0 dengan dosis cod liver oil dosis $0 \%$ antar setiap perlakuan yaitu P1 dengan dosis cod liver oil 3\%., perlakuan P2 dengan dosis cod liver oil 6\%. Perlakuan P3 dengan 
dosis cod liver oil 9\% dan pada perlakuan P4 dengan dosis cod liver oil 12\%.

Rata-rata Docosahexaenoic acid (DHA) pada perlakuan P0 dengan dosis cod liver oil $0 \%$ menunjukkan kandungan DHA 1,51\%. Pada perlakuan P1 dengan dosis cod liver oil 3\% mengalami peningkatan DHA 1,64\%. Perlakuan P2 dengan dosis cod liver oil $6 \%$ menunjukkan peningkatan DHA 2,47\% sedangkan pada perlakuan $\mathrm{P} 3$ dengan dosis cod liver oil 9\% mengalami penurunan 2,15\%. Perlakuan P4 dengan dosis cod liver oil $4 \%$ mengalami peningkatan 2,22\%. Pada penelitian kandungan DHA dosis tertinggi terdapat pada perlakuan P2 (6\%) yaitu $2,47 \%$ sedangkan dosis terendah terdapat pada perlakuan P0 (0\%) yaitu $1,51 \%$.

\section{Pembahasan}

\section{Ecosapentaenoic Acid (EPA)}

Hasil perhitungan Analysis of Variant (ANOVA) EPA menunjukan adanya perbedaan yang nyata $(\mathrm{p}<0,05)$. Berdasarkan hasil Uji Jarak Berganda Duncan (Duncan's Multiple Range Test) menunjukkan perlakuan P0 (0\%) sebagai kontrol berbeda nyata dengan perlakuan P4 (12\%), P3 (9\%) dan P2 (6\%). Kadar rata-rata Ecosapentaenoic Acid (EPA) terendah terdapat pada P1 (CLO 3\%) dengan rata-rata 3,63 \% sedangkan kadar EPA tertinggi pada perlakuan P4 (CLO $12 \%$ ) dengan nilai rata-rata $5,24 \%$.

Asam lemak omega-3 termasuk dalam kelompok asam lemak esensial. Asam lemak ini disebut esensial karena tidak dapat dihasilkan oleh tubuh dan hanya bisa didapat dari konsumsi makanan sehari-hari. Asam lemak dengan konfigurasi omega-3 adalah asam lemak yang memiliki posisi ikatan rangkap pertama pada atom karbon nomor 3 dari ujung gugus metilnya. Asam lemak yang termasuk dalam kelompok ini adalah asam eicosapentaenoat (EPA). Asam eicosapentaenoat (EPA) bermanfaat untuk mencegah kolestrol, pencegahan penyakit jantung dan kecerdasan otak. Asam eicosapen- taenoat (EPA) dihasilkan oleh alga dan pada hewan melalui desaturasi elongasi $\alpha$ linolenat menurut pendapat Manurung (2009).

Pada penelitian ini sumber asam lemak tak jenuh omega-3 (EPA) didapatkan dari cod liver oil yang ditambahkan pada pakan komersial udang galah (Macrobrachium rosenbergii). Cod liver oil memiliki kandungan asam lemak omega-3 21,97\% dan omega-6 2.56\%. Cod liver oil yang ditambahkan pada pakan komersial akan dimakan oleh udang dan diabsorbsi oleh tubuh udang galah.

Mekanisme penyerapan asam lemak omega 3 pada tubuh udang udang terjadi pada usus. Pakan yang dari usus masuk menuju hati menghasilkan garam empedu yang berfungsi mengemulsikan lemak menjadi asam lemak (EPA dan DHA). Asam lemak (EPA dan DHA) akan berubah menjadi gliserol karena dihidrolisis oleh enzim lipase. Asam lemak yang dari hati diedarkan melalui darah dengan bantuan reseptor lipoprotein yang berbentuk kilomikron sehingga dapat menghambat Very Low Density Lipoprotein (VLDL) sehingga dapat menaikkan High Density Lipoprotein (HDL) dan menurunkan Low Density lipoprotein (LDL). Asam lemak (EPA dan DHA) dan gliserol digunakan sebagai energi dan penyusunan selsel tubuh (Arifah, 2006).

Hasil perhitungan analisis of variant (ANOVA) EPA menunjukkan pengaruh yang berbeda nyata pada masing-masing perlakuan. Peningkatan dan penurunan EPA pada daging udang galah dipengaruhi oleh penambahan dosis cod liver oil yang diberikan pada pakan komersial tersebut. Hal ini sesuai dengan pendapat Chedoloh et al (2011) yang menyatakan bahwa komposisi daging udang sangat bervariasi tergantung pakan yang dimakan oleh udang tersebut selain itu faktor yang mempengaruhi adalah umur, musim dan habitat. 


\section{Docosahexaenoic Acid (DHA)}

Hasil perhitungan Analysis of Variant (ANOVA) DHA menunjukan adanya perbedaan yang tidak nyata $(\mathrm{p}>0,05)$. Berdasarkan hasil Uji Jarak Berganda Duncan (Duncan's Multiple Range Test) menunjukkan hasil perlakuan P0 (CLO 0\%), P1 (CLO 3\%), P2 (CLO 6\%), P3 (CLO 12\%), P4 (CLO 12\%) tidak berbeda nyata antara perlakuan kontrol dengan yang lainnya. Kadar rata-rata Docosahexaenoic acid (DHA) terendah terdapat pada P0 (CLO 0\%) dengan rata-rata 1,51\% sedangkan kadar DHA tertinggi pada perlakuan P2 (CLO 6\%) dengan nilai ratarata $2,47 \%$.

Asam dekosa-heksaenoat (DHA) bermanfaat untuk men-cegah kolestrol, pencegahan penyakit jantung dan kecerdasan otak. Menurut Manurung (2009) asam dekosaheksaenoat (DHA) pada hewan berasal dari $\alpha$ - linolenat yang terjadi melalui proses desaturasi atau elongasi $\alpha$ - linolenat menjadi 22:6n-3.

Hasil perhitungan analisis of varian (ANOVA) DHA menunjukkan pengaruh yang tidak berbeda nyata pada masing-masing perlakuan. Tidak berbeda nyata pada daging udang galah dikarenakan penyerapan nutrisi dalam saluran pencernaan udang. Hal ini sesuai dengan pendapat Caecaldi (1989) bahwa saluran pencernaan bertanggung jawab bagi banyak hewan dan krustasea khususnya untuk fungsi gizi. Penyerapan nutrisi makanan dimulai dalam mulut yang kemudian dilanjutkan ke kerongkongan dan menuju ke saluran pencernaan yaitu hepatopankreas atau kelenjar midgut diduga tidak terserap sempurna.

Hepatopankreas merupakan organ utama dalam dekapoda yang digunakan untuk metabolisme, sintesis dan sekresi enzim pencernaan, penyerapan produk makanan dicerna, produksi cadangan mineral dan zat organik. Hepatopankreas juga berperan dalam metabolisme lemak (Caecaldi, 1989).

Peningkatan dan penurunan DHA pada daging udang galah dipengaruhi oleh penambahan dosis cod liver oil yang diberikan pada pakan komersial tersebut.

\section{Metabolisme Omega-3 Pada Daging Udang Galah (Macrobrachium rosen- bergii)}

Peningkatan kandungan asam lemak omega-3 pada daging pada daging udang galah dipengaruhi oleh tingkat pemberian minyak ikan cod pada pakan komersial udang galah.

Kandungan asam lemak omega-3 dalam daging udang galah pada penelitian ini khususnya derivat omega-3 asam eikosapentaenoat (EPA) mengalami peningkatan omega-3 pada pakan diiringi dengan peningkatan asam lemak omega-3 dalam daging udang. Hal ini sesuai dengan pernyataan Cuzon et al (2003) menyatakan bahwa kandungan asam lemak yang terkandung dalam daging udang berasal dari asam lemak yang dikonsumsi oleh udang tersebut. Kandungan omega-3 pada daging tersebut disebabkan karena sebagian besar asam lemak tak jenuh disimpan dalam fosfolipid dari membran sel (Huang dkk 2006).

Asam lemak omega-3 pada perlakuan kontrol mengandung asam lemak tak jenuh yang lebih rendah dibandingkan dengan kandungan derivat omega-3 dari kelompok perlakuan. Hal ini disebabkan karena kadar asam lemak omega-3 di daging udang galah dari perlakuan P0 (kontrol) tidak mencukupi jumlahnya untuk melakukan proses metabolisme lebih lanjut yaitu elongasi yang berseling dengan desaturasi sehingga derivat omega3 yang lainnya. Hal ini sesuai dengan pendapat Linder (1991) akan terjadi kompetisi perlakuan enzim omega-6 desaturase dalam proses desaturasi dua kelompok yang termasuk asam lemak tak jenuh. Kompetisi tersebut akan dimenangkan oleh kelompok yang jumlahnya lebih besar.

Asam lemak yang dibentuk di dalam sel atau diperoleh dari makanan digunakan oleh berbagai jaringan untuk membentuk triasligliserol gliserofosfolipid dan spingolipid. Di hati trisigliserol diben- 
tuk dari asil lemak KoA dan gliserol 3fosfat. Pada jalur ini asam fosfatidat berfungsi sebagai zat antara. Triaslgliserol tidak disimpan di dalam hati tetapi dikemas bersama epolipoprotein dan lemak lain dalam lipoprotein berdensitas sangat rendah very low density lipoprotein (VLDL) dan diedarkan dalam darah. Di dalam kapiler berbagai jaringan (jari-ngan adiposa dan jaringan otot) mencerna triasilgliserol dan menghasilkan asam lemak dan gliserol. Gliserol menuju ke hati dan jaringan lain untuk dimanfaatkan. Sebagian asam lemak dioksidasi oleh otot dan jaringan lain. Asam lemak ini dibebaskan selama masa puasa dan berfungsi sebagai energi utama tubuh (Stryer, 2000).

\section{KESIMPULAN DAN SARAN Kesimpulan}

Pemberian pakan dengan penambahan cod liver oil pada pakan komersial mening-katkan kandungan EPA di daging udang galah. Kandungan EPA semakin meningkat pada perlakuan P2 dengan dosis $6 \%$ yaitu $4,69 \%$, sedangkan pemberian pakan dengan penambahan cod liver oil pada pakan komersial tidak meningkatkan kandungan DHA di daging udang galah. Kandungan DHA semakin menurun pada perlakuan P4 dengan dosis $12 \%$ yaitu $2,22 \%$ dan dosis tertinggi pada perlakuan $\mathrm{P} 2$ dengan dosis $6 \%$.

\section{Saran}

Berdasarkan penelitian yang telah dilakukan, penulis menyarankan agar dilakukan penelitian lanjutan dengan dosis yang berbeda untuk mengetahui efektifitas pemberian penambahan cod liver oil pada pakan komersial dalam meningkatkan kandungan EPA dan DHA udang galah (Macrobrachium rosenbergii).

\section{DAFTAR PUSTAKA}

Arifah.2006. Peran Lipoprotein dalam Pengangkutan Lemak Tubuh. Jurnal Kaunia Vol II (2):122-134

Ayu R . 2008 . Pengaruh Asam Lemak Jenuh Tidak Jenuh dan Asam
Lemak Trans Terhadap Kesehatan. Fakultas Kesehatan Masyarakat. Universitas Indonesia Depok. Jurnal Kesehatan Masyarakat Nasional Vol. 2, No. 4, Februari 2008.

Caecaldi, H.J. 1989. Anatomuy and Physiology of Digestive Tract of Crustacean Decapod Reared in Aquacultured Infremer. Acted De Colloque 9 pp.243-259.

Chedoloh, R., Karilla, T.T and Pakdeechanuan P. 2011. Fatty Acid Composition Of Important Aquatic Animals in Southern Thailand. International Food Research Journal 18:783-790.

Cuzon, G. Addison L, Gabriela. G. Carlos.S. dan J.Guillaume. 2003. Nutrition of Litopenaeus vannamei reared in tanksor in Ponds.Elsevier. Aquaculture 235(2004) 513-551.

Fatagar, S. H. 2014. Jumlah Konsumsi Pakan Udang Galah (Macrobrachium rosenbergii) yang Diberi Pakan Atraktan Berbeda. Skripsi. Budidaya Perairan. Fakultas Perikanan dan Ilmu Kelautan. Institut Pertanian Bogor. Bogor. hal. 3.

Linder,M.C. 1991. Nutrition and metabolism of fats (Maria C Linders Eds). In Nutrional Biochemistry and Metabolism. Connecticut: Apleton and Lange PP.51-83.

Harlver, J.E. 1989. Fish Nutrition Second Edition. Academic Press. Inc. San Diego. California.

Huang,J.F., C.C.Huang., M.K.Lai.,J.H. Lin.,C.H.Lee and T.Y.Wang. 2006. Effect of eicosapentaenoat acid and docosahexaenoat acid and sensory evaluation of the breast meat in muleducks. Asian -Aust J.Anim.Sci.Vol 19 (2):231-235.

Kepala Pusat Penyuluhan Kelautan dan Perikanan. 2011. Modul Materi Penyuluhan Budidaya udang Galah. Jakarta hal 3.

Manurung. D.M. 2009. Komposisi Kimia Asam Lemak dan Kolestrol Udang 
Akibat Perebusan Skripsi. Departemen Teknologi Hasil Perikanan dan Kelautan Institut Pertanian Bogor.

Kusriningrum, R. S. 2012. Perancangan Percobaan. Airlangga University Surabaya Press. hal 16-17.

Stryer, L. 2000. Biokimia.Vol.2 Edisi 4 Terjemahan:Sjahbarar S.Z dan Evi S.EGC. Jakarta hal 603-605.

Yola, R. I. 2015. Penambahan Cod Liver Oil Pada Pakan Komersial Terhadap Kandungan Derivat Omega3 Daging Udang Vannamei (Litopenaeus vannamei). Skripsi. Program Studi Budidaya Perairan. Universitas Airlangga Surabaya.

Yustianti, M. N. Ibrahim dan Ruslaini. 2013. Pertumbuhan dan Sintasan Larva Udang Vanamei (Litopenaeus vannamei) Melalui Substitusi TepungI kandungan Tepung Usus Ayam. Jurnal Mina Laut Indonesia 1(1): 93-103. 